Papers and Proceedings of the Royal Society of Tasmania, Volume 116, 1982

(ms. received 15.10 .81 )

\title{
LATE PLEISTOCENE MARINE MOLLUSCAN FAUNAS FROM FOUR SITES IN TASMANIA
}

\author{
by Eric A. Colhoun, Elizabeth Turner and Guus van de Geer \\ University of Tasmania (E.A.C. and G.vdG.),
} and Tasmanian Museum and Art Gallery

(with two tables and one text-figure)

ABSTRACT

COLHOUN, E.A., TURNER, E. and van de GEER, G., 1982 ( 31 viii): Late Pleistocene marine molluscan faunas from four sites in Tasmania. Pap. Proc. R. Soc. Tasm., 116: $91-96$. https://doi.org/10.26749/rstpp.116.91 ISSN 0080-4703. Department of Geography, University of Tasmania, and Tasmanian Museum and Art Gallery, Hobart, Tasmania.

Species lists of Late Pleistocene interglacial molluscan faunas and details of their occurrence are given for four sites in Tasmania. The faunas occur in former shallow coastal embayments, and inner and outer estuarine shallow water environments. All of the species are extant.

\section{INTRODUCTION}

During recent work on Quaternary sea level changes in Tasmania (van de Geer et al. 1979; van de Geer, in prep.) collections of marine molluscs were obtained from Broadmeadows and Montagu in northwestern Tasmania, and from Swansea and Mary Ann Bay in eastern Tasmania (fig. 1). Although moulds and fragments of marine shells have been encountered from time to time by various workers in the pre-Holocene coastal marine sands of Tasmania, the acid groundwater environment of most of the island does not favour good preservation. The few substantive faunal records obtained to date come from sites underlain by either limestones or dolerites and they are recorded here together with comments on their occurences. The collections have been catalogued and placed in the Tasmanian Museum and Art Gallery, Hobart, for future reference.

\section{BROADMEADOWS}

The molluscan fauna consisted of 51 species that were in a good state of preservation, some bearing their original surface colouring (table 1). They were recovered from a section in a drainage ditch located at grid reference 366731 (Tasmanian 1:100 000 Topographic Map Series, Sheet 7916, First Edition) where, beneath the surface peaty soil, there is more than one metre of marine fine sands overlying Precambrian dolomite. Fluctuations of the groundwater table in the upper 0.1-0.15 $\mathrm{m}$ of the sands had reduced the shells to moulds and had recemented the sands with carbonates, but below the permanent water table the shells were abundant and perfectly preserved. There were very few broken or wave-worn shells. The fauna occurs at $13 \mathrm{~m}$ above present high water mark and $6 \mathrm{~km}$ from the sea.

\section{MONTAGU}

Sixty-eight species of Mollusca were encountered in fine marine sands beneath the surface peaty soil in a pit dug at grid reference point 274829 (Sheet 7816, First Edition) (table 1). The shells were very well preserved and most bear their original surface colourings. As at Broadmeadows, the shell material in the surface 0.1 to $0.15 \mathrm{~m}$ has been reduced to moulds and the sands have been recemented with carbonate, but below the permament water table the shells are so well preserved that few are broken or strongly waveworn. The marine sands are underlain by Tertiary limestones. The shells occur at $11 \mathrm{~m}$ above present high water mark and are $3 \mathrm{~km}$ from the sea. 


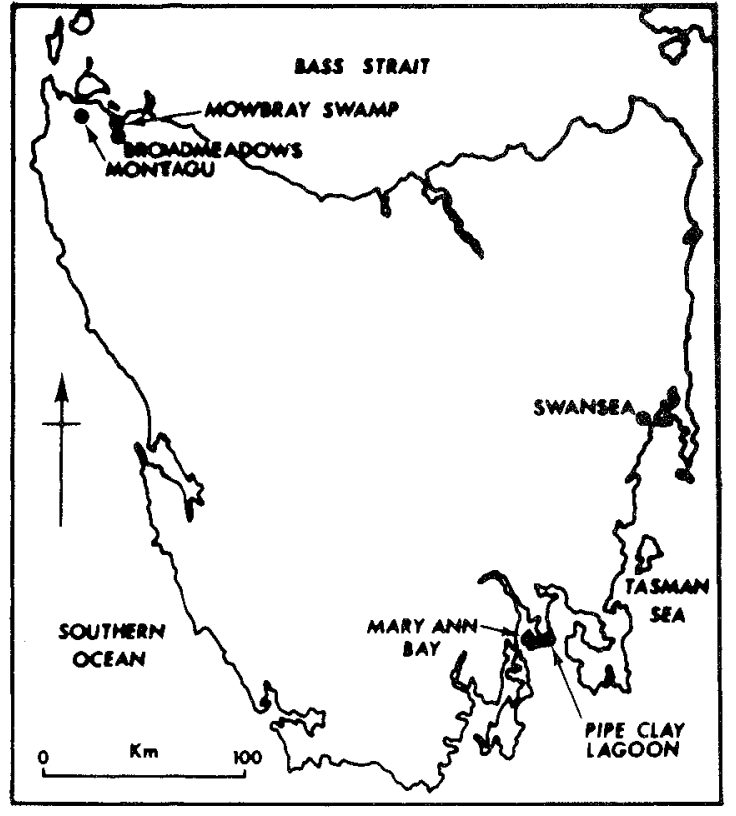

SWANSEA

Nine species of Mollusca were obtained from a pit dug in the bottom of a deep drainage ditch at grid reference 876393 (Sheet 8513, First Edition) and west of Wet Marsh Bridge $4 \mathrm{~km}$ north of Swansea (table 2). The shells occur $6.4 \mathrm{~m}$ above present high water mark and $3 \mathrm{~km}$ from the sea. They are enclosed within very stiff, waterlogged sandy clay which is sealed by more than a metre of black alluvial clay that forms the surface of the terrace at approximately $8 \mathrm{~m}$ above present high water mark. The underlying rock is Jurassic dolerite. The shells are well preserved but are delicate and break easily during extraction from the clay. Although the complete assemblage was recorded from this site, five species, Austrocochlea constricta zebra, ?Diala lauta, Ostrea angasi, Notospisuza trigonelza and Telzina deltoidalis (table 2) were also encountered at another site east of Wet Marsh Bridge and 1 km nearer the sea (N.K. Chick and W. Cromer, pers. comm.) .

FIG. 1.- Locality map.

MARY ANN BAY

From an open cliff section 49 molluscan species were obtained in fine to medium marine sands and silts at grid reference 322417 (Sheet 8312, First Edition) on the South Arm Peninsula at the mouth of the Derwent estuary (table 2). The marine deposits overlie a bench on top of the Jurassic dolerite cliffs and extend up to at least $22 \mathrm{~m}$ above present high water mark. Although sparse shell fragments can be found throughout the marine deposits, she11s are only really abundant between 20 and $21 \mathrm{~m}$ above HWM and immediate1y beneath the surface soil profile. The shell beds dip gently seaward at $5-15^{\circ}$, towards the mouth of the Derwent. The shells are moderately well-preserved but some decalcification has taken place by soil forming processes which gives the shells a powdery surface appearance and free carbonate has been precipitated on the vertical joints. The surface of the marine deposits at $22 \mathrm{~m}$ above HWM is not original as it has been deflated by severe wind erosion subsequent to deposition (Colhoun 1975).

\section{COMENTS}

These fossil molluscan faunas do not contain any extinct species and consist only of species living today in intertidal and shallow offshore areas of Tasmania (May 1923; Kershaw 1958). The fossil status of these assemblages is unequivocal. All occur either long distances inland or at considerable height above Holocene marine deposits, or both. The pre-last glacial age of the Broadmeadows and Montagu faunas is indicated by their occurrence within fine marine sands which are stratigraphically continuous with marine sands that occur beneath organic soils and swamp peats that have been radiocarbon dated to more than 52000 years B.P. (GrN-9342) at Mowbray Swamp (van de Geer, in prep.). The pre-last glacial age $(\sim 25000$ to 10000 B.P.) of the Swansea and Mary Ann Bay faunas is supported by the facts that the clay deposits of the former have been deflated to form a lunette dune, and the sands of the latter have been deflated to produce a $13 \mathrm{~m}$ deep 
Eric A. Colhoun, Elizabeth Turner and Guus van de Geer

enclosed hollow. Such wind action in southeastern Tasmania with the development of dune landforms and erosion of deflation hollows has been radiocarbon dated to younger than $25300 \pm 640$ years B.F. at Pipe Clay Lagoon (SUA-151) (Colhoun 1977). The faunas cannot be differentiated in age and their stratigraphic relationship with other sediments and landforms suggests that they are likely to belong to the period of interglacial high sea level that preceded the last glaciation, viz. the Last Interglacial.

Although the geomorphological environments are easily reconstructed there is very little detailed knowledge of the present ecology of Tasmanian Mollusca so that on $1 y$ a very general assessment of the palaeoenvironments is possible by ecological analogy. The shell assemblage at Broadmeadows is dominated by subtidal pelecypods; species that mainly occur in association with beach backwash deposits near low tide mark along the shores of open sandy embayments. This is consistent with the geomorphological evidence which indicates that a broad sandy marine embayment occurred in the area. In contrast, the Montagu fauna contains a greater number of species than the Broadmeadows fauna and includes more gastropods that prefer rock substrates to live on. The mixed character of the fauna with some species preferring sandy conditions and others rocky habitats indicates that the fossil enviromment of Montagu was probably that of a quiet sandy bay protected from strong wave action by intertidal and subtidal reefs, as occurs today off the far northwestern coastline.

The Swansea fauna is markedly different from any of the others and contains four species, Austrocochzea constricta zebra, clanoulus dunkeri, Katelysia rhytiphora and Tellina deltoidalis not found at the other sites. The abundance of small gastropods and their perfect preservation, in addition to the sandy clay texture of the deposits, indicates that they were deposited in the inner part of a shallow-water estuary. This estuary can be traced as a geomorphological feature that connects with the sea at Nine Mile Beach and the mouth of the Swan River.

The Mary Am Bay shell deposit is dominated by Pecten mexidionalis and approximately half the fauna consists of gastropods and half pelecypods. This indicates that the palaeoenvironment consisted of a variety of sandy/silty and rocky substrates similar to those available near the mouth of the Derwent estuary today. This interpretation is consistent with the geomorphological evidence for an outer estuarine environment during the Last Interglacial high sea level phase, which in Tasmania is believed to have attained a relative height of at least $21 \mathrm{~m}$ above present high water mark (van de Geer et al. 1979).

\section{ACKNOWLEDGEMENT}

We thank Robert Burn of Geelong for identifying the species of Retusidae, Winston Ponder of the Australian Museum, Sydney, Alison Green of the Tasmanian Museum and Art Gallery, Hobart, and Dr N.H. Ludbrook, Adelaide, for their help in identification of the shells.

\section{REFERENCES}

Colhoun, E.A., 1975: A Quaternary climatic curve for Tasmania. Austr. Conf. on Climate and Climatic Change, Royal Met. Soc., Monash Univ., Dec. 7-12, 1975: 39 pp.

1977: A sequence of late quaternary deposits at Pipe Clay Lagoon, southeastern Tasmania. Pap. Proc. R. Soc. Tasm., 111: 1-12

Kershaw, R.C., 1958: Tasmanian intertidal Mollusca. J. malacol. Soc. Austr., 2: 58-100. May, W.L., 1923: AN ILLUSTRATED INDEX OF TASMANIAN SHELLS. Government Printer, Hobart. van de Geer, G., in prep.: LATE QUATERNARY MARINE AND FRESHWATER SWAMP DEPOSITS OF NORTHWESTERN TASMANIA. Ph.D. thesis, University of Tasmania.

van de Geer, G., Colhoun, E.A. and Bowden, A.R., 1979: Evidence and problems of interglacial marine deposits in Tasmania. Geol. en Mijmbouw, 58(1): 29-32. 


\section{TABLE 1}

\section{NORTHWESTERN TASMANIA}

Hemitoma subemarginata (Blainville, 1819)

Patelzoida profunda calamus (Crosse \& Fischer, 1864)

Austrocochlea concamerata (Wood, 1828)

Austrocochlea constricta (Lamarck, 1822)

Austrocochlea odontis (Wood, 1828)

Bankivia fasciata (Menke, 1830)

Calziostona australe? (Broderip, 1835)

ClancuZus Zimbatus (Quoy G Gaimard, 1834)

clancuZus plebejus (Philippi, 1851)

phasianotrochus mutilis (A. Adams, 1851)

Thatotia conica (Gray, 1827)

Phasianeiza sp.

Turbo undulatus (Solander, 1786)

Eatoniella sp.

Powe Zlisetia simizlima (May, 1915)

Badepigms badius (Petterd, 1884)

Pisinna frenchiensis (Gatliff \& Gabriel, 1908)

Gazameda tasmanica (Reeve, 1849)

Serpulorbis sipho (Lamarck, 1818)

Zeacumantus diemenensis (Quoy \& Gaimard, 1834)

Bittium granarium (Kiener, 1842)

Hypotrochus monachus (Crosse \& Fischer, 1864)

Notosinister festiva? (A. Adams, 1851)

Notosinister pfeifferi (Crosse \& Fischer, 1865)

MeZanezza sp.

Agatha metealfei (Pritchard \& Gatiiff, 1900)

Chemnitzia mariae (Tenison Woods, 1876)

Sigapatelza calyptraeformis (Lamarck, 1822)

Zeacrypta immersa (Angas, 1865)

Ectosinum zonale (Quoy \& Gaimard, 1833)

Folinices incei (Philippi, 1851)

Polinices conicus (Lamarck, 1822)

Folinices sordidus (Swainson, 1821)

Folinices aulacoglossa (Pilsbry \& Vanatta, 1908)

Eunaticina umbilicata (Quoy and Gaimard, 1900)

Notocrypraea angustata (Gmelin, 1791)

Cymatielza vermoosa (Reeve, 1844)

Negyrina subdistorta (Lamarck, 1822)

Bedeva paivae (Crosse, 1864)

Pterynotus triformis (Reeve, 1845)

Lepsielza vinosa (Lamarck, 1822)

Dentimitrelza sp.

Macrozafra atkinsoni (Tenison Woods, 1875)

Pseudamyela miztostoma? (Tenison Woods, 1876)

Cominezza Zineolata (Lamarck, 1809)

Penion maxima (Tryon, 1881)

Nassarius nigelius (Reeve, 1854)

Nassarius pauperata (Lamarck, 1822)

Pleuroploca australasia (Perry, 1811)

Amalda petterdi (Tate, 1893)

Cupidoliva numpha (Adams \& Angas, 1863)

Amorena undulata (Lamarck, 1804)

$\mathrm{x}$

$\mathrm{x}$ 
Eric A. Colhoun, Elizabeth Turner and Guus van de Geer

Montagu

Cancezzaria sp. C. spirata Lamarck, 1822 or

C. Zactea Deshayes, 1832

C. grarzosx (Sowerby, 1832)

Sinuginella pygmaeoides (Singleton, 1937)

Epidirona quoyi (Reeve, 1843)

Guraleus pietus (Adams \& Angas, 1863)

Mitraguraleus australis (A. Adams \& Angas, 1863)

Broadmeadows

Pervicacia bicolor (Angas, 1867)

Acteocina sp.

Retusa atkinsoni (Tenison Woods, 1875)

Retusa sp.

Retusa sp. + Retusa sp. nov.

Salinator fragitis (Lamarck, 1822)

Siphonaria diemenensis Quoy \& Gaimard, 1833

Cadulus vincentianus Cotton \& Godfrey, 1940

Glycymeris sp.

Glycymemis striatuzaris (Lamarck, 1819)

Mytizus planulatus (Lamarck, 1819)

Chzamys aspermima (Lamarck, 1819)

Pecten meridionalis Tate, 1886

ostrea angasi Sowerby, 1871

Neotrigonia margaritacea (Lamarck, 1804)

Cuna concentrica Hedley, 1902

Venericardia bimaculata (Deshayes, 1852)

Cyamiomactra mactroides (Tate \& May, 1900)

Divalueina cumingi (A. Adams \& Angas, 1863)

Myrtea botanica Hedley, 1918

Wallucina assimilis (Angas, 1867)

Bomia trigonale (Tate, 1879)

Mysezza donaciformis Angas, 1878

Eulvia tenuicostata (Lamarck, 1819)

Notocaliista diemenensis (Hanley, 1844)

Caltanaitis disjecta (Perry, 1811)

Chioneryx cardioides (Lamarck, 1818)

Eumarica fumigata (Sowerby, 1853)

Katezysia peronii (Lamarck, 1818)

Placamen placida (Philippi, 1844)

Tawera galiinula (Lamarck, 1818)

Irus distans (Lamarck, 1818)

Irus (Notopaphia) grisea (Lamarck, 1818)

Mesodesma erycinaea (Lamarck, 1818)

Gari livida Lamarck, 1818

Pseudarcopagia botanica Hedley, 1917

Hiatelza australis (Lamarck, 1818)

Panopea australis Soweeby, 1833

Myadora brevis (Sowerby, 1829)

Myadora complexa Iredale, 1924 
PateZZanax chapmani (Tenison Woods, 1876)

Notoacmea flarmea (Quoy \& Gaimard, 1834)

Patelloida profunda calamus (Crosse \& Fischer, 1864)

Austrocochlea constricta zebra (Menke, 1829)

Bankivia fasciata (Menke, 1830)

Clanoulus dunkeri (Koch, 1843)

Hydrococcus brazieri (Tenison Woods, 1876)

Microdiscula charopa (Tate, 1899)

Ctenocolpus australis (Lamarck, 1822)

Zeacumantus diemenensis (Quoy \& Gaimard, 1834)

Cacozeliana granaria (Kierner, 1842)

Diala Zauta A. Adams, 1862

Seila albosutura (Tenison Woods, 1876)

Symola tincta Angas, 1871

Clypeola hedreyi (Smith, 1915)

Sigapatella calyptraeformis (Lamarck, 1822)

Zeacrypta immersa (Angas, 1965)

Notocochlis sp.

Polinices conicus (Lamarck, 1822)

Bedeva paivae (Crosse, 1864)

Benthoxystus petterdi (Crosse, 1870)

Comine Zza lineolata Lamarck, 1809

Dentimitrelza spp.

Nassamius nige ZZus (Reeve, 1854)

Nassarius pauperata (Lamarck, 1822)

Eusus novaehoilandiae Reeve, 1848

Pleuroploca australasia (Perry, 1811)

Guraleus alucinans (Sowerby, 1896)

Guraleus incmstus (Tenison Woods, 1876)

Leionucula obliqua (Lamarck, 1819)

Glycymeris sp.

Mytilus planulatus (Lamarck, 1819)

Chlamys asperrima (Lamarck, 1819)

Chlamys atkinos (Petterd, 1886)

Equichlomys bifrons (Lamarck, 1819)

Pecten meridionalis Tate, 1886

Ostrea angasi Sowerby, 1871

Cardita calyculata (Linné, 1758)

Venericardia bimaculata (Deshayes, 1852)

Divalucina cumingi (A. Adams \& Angas, 1863)

Lasaea australis (Lamarck, 1818)

Fulvia tenuicostata (Lamarck, 1819)

Notocallista kingi (Gray, 1827)

Chioneryx cardioides (Lamarck, 1818)

Katelysia rhytiphora Lamy, 1937

Katelysia sp.

Placamen placida (Phi1ippi, 1844)

Tawera galiinula (Lamarck, 1818)

Mesodesma erycinaea (Lamarck, 1818)

Mactra jacksonensis (Smith, 1885)

Notospisula trigonelia (Lamarck, 1818)

Gari Zivida (Lamarck, 1818)

Tellina albinelza Lamarck, 1818

Telzina deltoidalis Lamarck, 1818 
Papers and Proceedings of the Royal Society of Tasmania, Volume 116, 1982

(ms . received 6.5 .1981$)$

\title{
THE BRYOPHYTES OF THE MT WELLINGTON RANGE, TASMANIA
}

by D.A. and A.V. Ratkowsky

CSIRo, Hobart and Sandy Bay, Tasmania

(with five tables)

\author{
ABSTRACT
}

RATKOWSKY, D.A. and A.V., 1982 (3I viii): The bryophytes of the Mt Wellington Range, Tasmania. Pap. Proc. R. Soe. Tasm., 116: 97-I15. ISSN 0080-4703. C.S.I.R.O., Hobart, Tasmania.

A census of the bryophyte flora of the Mt Wellington Range, Tasmania, is reported, the field work having been carried out between 1 May 1977 and 31 October 1980. The survey area was similar in extent to that used by the authors in an earlier survey of the vascular plants. A total of 164 mosses and 130 liverworts was found in the survey area, representing more than $60 \%$ of the known Tasmanian bryophyte flora, including several species not previously known to occur in Tasmania. The number of moss species was greatest at middle and lower altitudes whereas the number of liverwort species was greatest at middle and higher altitudes. Reports of liverwort species in this census are accompanied by references to works containing descriptions and drawings, wherever possible, of these species. Only a few species known from past information or collections to have occurred on Mt Wellington were missing in the current survey despite the devastating bushfire of 7 February 1967.

\section{INTRODUCTION}

Serious efforts were made to study the bryophyte flora of Tasmania before that of most other parts of Australia. Bastow (1886-87) published a four-part paper (with an illustrated fold-out key) on the Tasmanian mosses and within thirty years Rodway (1913-14) brought out an extensive revision. Similarly, Bastow (1888) published an illustrated account of the Tasmanian liverworts, and Rodway (1917) provided an extensive revision. Although Rodway recognized that many of his "species" were really different forms of the same species and therefore not fully deserving of specific rank, it was only relatively recently that bryologists have brought into synonymy many of these forms previously considered to be distinct. Indeed, the plasticity of many species both in their vegetative and reproductive organs is probably at least as great as in the flowering plants, and perhaps bryologists of the future will increase the list of synonyms still further. Since Rodway's time many genuine new species have been added to the bryophyte flora of Australasia (including Tasmania) due to the efforts of such workers as H.N. Dixon, G.0.K. Sainsbury, J.H. Willis, E.A. Hodgson, K.W. Allison, R. Grolle and R.M. Schuster.

\section{SURVEY AREA AND VEGETATION ZONES}

The field work for the present survey was carried out between 1 May 1977 and 31 october 1980, the survey area used being the same as that employed for a census of the vascular plants of the Mt Wellington Range (Ratkowsky \& Ratkowsky 1976). Details of the vegetation zones occurring within the survey area are given in that paper and will not be repeated here, although Table 1 summarizes the main features and approximate elevations of each zone. Unlike the earlier survey where a minimum elevation of $240 \mathrm{~m}$ was employed in order to make a comparison with a previously published survey, no lower elevation limit was used in the present survey, except that bryophytes growing in the vicinity of habitation were not included.

\section{CENSUS OF THE MOSSES}

An important publication subsequent to the revision of the moss flora by Rodway (1913-14) was the eight-part commentary of Sainsbury (1953-56) on the moss species in 